\title{
POSTMODERNISTYCZNY KONSUMPCJONIZM JAKO ANTROPOGENNE ZAGROŻENIE XXI WIEKU
}

Jednym z największych wyzwań XXI wieku jest globalne powstrzymanie konsumpcyjnej mentalności człowieka, prowadzącej do degradacji środowiska naturalnego oraz do degradacji środowiska ludzkiego. Nastawienie konsumpcyjne, wywołujące coraz to nowe potrzeby człowieka i nowe sposoby ich zaspokajania, ostatecznie obraca się przeciwko człowiekowi i prowadzi do wytworzenia nawyków konsumpcyjnych i stylów życia obiektywnie niegodziwych i szkodliwych dla fizycznego i duchowego zdrowia ${ }^{1}$. Konsumpcyjna mentalność obejmuje wszystkie dziedziny życia, zarówno osobistego, jak i społecznego. Kieruje się prostą zasadą życiową - ,więcej mieć”, zapominając o „,być”. Konstytucja duszpasterska o Kościele w świecie współczesnym „, Gaudium et spes” podkreśla, że „,niemała grupa ludzi, zwłaszcza w krajach rozwiniętych gospodarczo, wydaje się być tak podporządkowana gospodarce, że niemal całe ich życie osobiste i społeczne jest nacechowane nastawieniem ekonomicznym"2. Źródłem takiego stylu życia jest współczesny materialistyczny i utylitarystyczny sposób myślenia i patrzenia na świat, zapoczątkowany przez nurt postmodernistyczny. Ekstremalny materializm prowadzi do degradacji wartości ludzkich i duchowych.

Artykuł składa się z dwóch części. Celem pierwszej jest ukazanie socjologicznych i teologicznych symptomów postmodernizmu. W dalszej części zaprezentowane zostanie materialistyczne pojmowanie świata spowodowane dominacją konsumpcjonizmu w życiu społecznym. 


\section{SOCJOLOGICZNE I TEOLOGICZNE SYMPTOMY POSTMODERNIZMU}

Współcześnie obserwować można zmiany w sposobie myślenia i opisu świata. Nowe tendencje w kulturze, filozofii, nauce, życiu społecznym i politycznym często określa się jako ponowoczesne. Pojęcie „ponowoczesny” wprowadził do języka filozofii i socjologii kultury Jean-François Lyotard książką pt. Kondycja ponowoczesna. Raport o stanie wiedzy (La condition postmoderne. Rapport sur le savoir, 1979). Praca ta jest uważana za manifest nowego kierunku myślenia. Historyk idei, Jerzy Szacki, analizując powyższą publikację, przedstawił w oparciu o nią, socjologiczną wizję współczesnego społeczeństwa, w której na pierwszy plan wysuwają się zjawiska takie jak konsumpcja (większa część społeczeństwa nie produkuje, a jedynie zużywa dobra materialne), intensywny obieg informacji (rosnąca kreacyjna potęga środków masowego przekazu zastępuje odbiorcom bezpośredni ogląd rzeczywistości), zjawisko nomadyzmu kulturowego (jednostki nie przywiązują się do jednego miejsca i profesji), manipulacja ośrodków władzy za pomocą public relations, które zastąpiły tradycyjne techniki kierowania społeczeństwem, eliminacja tradycyjnych metanarracji wyznaczających sens życia, rozpad spójnego kanonu kulturowego, postępujący kryzys tożsamości (wobec rozkładu tradycyjnych punktów odniesienia: grup społecznych, państw narodowych, ośrodków religijnych); w przypadku społeczeństwa ponowoczesnego można mówić o braku pojęcia całości ${ }^{3}$. Socjolog Janusz Ziółkowski, analizując z kolei poglądy badaczy takich jak: Oswald Spengler, Ortega y Gasset, Christopher Dawson, Arnold J. Toynbee, Karl Jaspers, Karl Mannheim, Johan Huizinga, Pitirim Sorokin, Emmanuel Mounier, Daniel Bell, doszedł do wniosku, że: „(...) wszyscy oni wykrywają te same objawy kryzysu kultury i cywilizacji współczesnej: sekularyzację i odejście od religii jako źródła wartości; relatywizm i subiektywizm moralny; odrzucenie autorytetów: prymat wartości zmysłowych nad wartościami duchowymi; hedonizm, oportunizm, utylitaryzm; pogłębiający się stale rozbrat między rozwojem nauki i techniki, postępem materialnym a postępem duchowym; nihilizm, poczucie beznadziejności, absurdalności życia i świata"4. Do podobnych spostrzeżeń doszedł również Zygmunt Bauman. Jego zdaniem zagadnienie ponowoczesności wiąże się z tożsamością, a dokładniej z tzw. „tożsamością indywidualną", której istota obejmuje dwa aspekty: ciągłość (każda osoba posiada indywidualne cechy charakterystyczne, niezmieniające się z upływem czasu) i poczucie odrębności (konstytuują ją cechy wyjątkowe) ${ }^{5}$. Otóż w społeczeństwie tradycyjnym tożsamość ta jest stała, uporządkowana, przewidywalna i niezmienna, a obowią-

J. Szacki, Historia myśli socjologicznej, Wydawnictwo Naukowe PWN, Warszawa 2004, s. 917.

J. Ziółkowski, Kryzys wartości, „Communio” 1983, nr 6, s. 33.

5 Por. Z. Bauman, Ponowoczesne wzory osobowe, „Studia Socjologiczne” 1993, nr 2, s. 9. 
zujące normy i wartości cenione są przez społeczeństwo. W erze ponowoczesności wszystkie powyższe aspekty podlegają ciągłej zmianie, stają się ulotne, tymczasowe i niepewne. Zdobyte wykształcenie, zawód, miejsce pracy i zamieszkania, pozycja w społeczeństwie ulegają ciągłej zmianie - to, co dzisiaj jest wartościowe, jutro już traci swoją pozycję i zmusza jednostkę ludzką do poszukiwania nowych umiejętności. W takiej sytuacji posiadanie silnie zdefiniowanej tożsamości jest przeszkodą w osiągnięciu zrównoważonego stosunku emocjonalnego wobec aktualnej sytuacji życiowej. W społeczeństwie ponowoczesnym tożsamość osoby ulega ciągłej przemianie, zarówno w relacji do innych osób, jak i do miejsca ${ }^{6}$. Anthony Giddens z kolei, socjolog brytyjski, w swych analizach społeczeństwa ponowoczesnego stwierdza, iż człowiek żyjący w tym świecie niepewności jest nieustannie zmuszany do nowych wyborów, to zaś prowadzi do dyferencjacji sposobów życia i autorytetów oraz braku poczucia zakorzenienia ${ }^{7}$.

Bezsprzecznie postmodernizm nie jest zjawiskiem jednolitym o ściśle określonej definicji. Przedstawione powyżej jego symptomy wskazują, że ,czuje się” go poprzez relatywizm, charakteryzujący współczesność. Zwraca na ten fakt uwagę Ernest Gellner, pisząc: „Postmoderniści dość otwarcie opowiadają się za relatywizmem, ponieważ ma on pewną zdolność wyjaśniania, jednocześnie jest wrogiem idei unikatowej, wyłącznej, obiektywnej, zewnętrznej i transcendentnej prawdy"s. Do podobnych wniosków doszli również teologowie. Zasadniczą cechę postmodernizmu upatrują w zanegowaniu roli rozumu i logicznego myślenia w procesie poznawczym. Kamuflowany etykietą naukowości antyracjonalizm i dekonstrukcjonizm uprawomocnia postawy takie, jak relatywizm etyczno-aksjologiczny, depersonalizujący indywidualizm i konsumpcjonizm ${ }^{9}$. Ks. Waldemar Chrostowski zwraca uwagę na charakterystyczny, wszechpanujący pluralizm (w znaczeniu metody uznającej przewagę różnicy nad jednością), pragmatyzm w relacji z „,drugim", a także irracjonalizm i anarchizm metodologiczny w dziedzinie poznawczej ${ }^{10}$.

Relatywizm etyczno-aksjologiczny związany jest z odrzuceniem obowiązujących kryteriów prawdy, a co za tym idzie - nieuznawaniem uniwersalnych wartości. Człowiek staje się kreatorem prawdy. Istnieje wielość prawd, ponieważ każdy stanowi o własnej prawdzie, którą tworzy w oparciu o subiektywne doświadczenie. O niebezpieczeństwie takiego redukcjonistycznego i nihilistycznego podejścia pisał Jan Paweł II w encyklice Fides et ratio. Niebezpieczeństwo to

6 Por. tamże, s. 14-23.

7 Por. A. Giddens, Nowoczesność i tożsamość. ,„Ja” i spoleczeństwo w epoce późnej nowoczesności, Wydawnictwo Naukowe PWN, Warszawa 2001, s. 9.

8 E. Gellner, Postmodernizm, rozum i religia, tłum. M. Kowalczuk, Państwowy Instytut Wydawniczy, Warszawa 1997, s. 37.

9 Por. M. Chmielewski, Postmodernizm, w: Leksykon duchowości katolickiej, red. M. Chmielewski, Wydawnictwo M, Lublin - Kraków 2006, s. 685.

10 Por. W. Chrostowski, Moderniści, postmoderniści i inni, „Ethos” 1996, nr 1-2, s. 5. 
doprowadziło do: „(...) powstania różnych form agnostycyzmu i relatywizmu, które sprawiły, że poszukiwania filozoficzne ugrzęzły na ruchomych piaskach powszechnego sceptycyzmu. Doszły więc do głosu różne doktryny próbujące podważyć wartość nawet tych prawd, o których pewności człowiek był przekonany. Uprawniona wielość stanowisk ustąpiła miejsca bezkrytycznemu pluralizmowi, opartemu na założeniu, że wszystkie opinie mają równą wartość"11. Wszechobecny relatywizm sprawia, że wszelkie papieskie dokumenty, wiernie trzymające się nauki Chrystusa i Kościoła opatrywane są etykietą katolickiego fundamentalizmu i wstecznictwa ${ }^{12}$. „Nihilizm. Będąca w modzie ideologia neguje potrzebę i wartości postaw o charakterze ostatecznym, zarówno immanentnych, jak i transcendentnych, które thumaczyłyby lub uzasadniłyby wieloaspektowość rzeczywistości, albo które funkcjonowałyby jako kryterium prawdy teoretycznej lub aksjologicznej (tzn. takich, które stanowiłyby podstawę i dałyby moc obowiązującą wartościom ukierunkowującym życie człowieka i społeczeństwa)" - napisał hiszpański teolog J. J. Garrido ${ }^{13}$. Papież Benedykt XVI stwierdził - odnosząc się do niebezpieczeństwa relatywizmu: „Żyjemy w czasach charakteryzujących się w znacznym stopniu nieświadomym relatywizmem, który przenika wszystkie dziedziny życia. Niekiedy ów relatywizm staje się wojowniczy, atakując ludzi, którzy twierdzą, że wiedzą, gdzie można znaleźć prawdę i sens życia" ${ }^{14}$. Antyracjonalność i pluralizm prawd zburzyły podstawy klasycznej nauki. Wiedza przestała pełnić funkcje kształcenia ducha, a stała się informacją. Świat jawi się jako zbiór chaotycznie nagromadzonych elementów. Lansowany system kształcenia dyspozycyjnego daje uczniowi minimum wiedzy encyklopedycznej o otaczającym go świecie i niezbędne umiejętności korzystania z osiągnięć najnowszej technologii, ale brakuje mu krytycznego myślenia, zdolnego dociekać ostatecznych przyczyn rzeczy i zjawisk. W poznawaniu otaczającej rzeczywistości liczy się przede wszystkim osobiste doświadczenie i intuicja. Postmoderniści uważają, że jedynie prawdziwe jest to, co przyjemne. Hedonizm staje się filozofią życia. Dla osiągnięcia dojrzałości trzeba „wszystkiego” doświadczyć. Stąd do głosu dochodzi niczym nieskrępowana seksualność ${ }^{15}$. „Miłość jest więc całkowicie oddzielona od całego zespołu swych warunków potencjalnych i realnych: staje się grą, ale współzależnie uprzedmiotawia się; ludzie już się nie kochają, ale uprawiają miłość" - stwierdził Dominique Folscheid ${ }^{16}$. W wyniku takich postaw również osoba ludzka ulega uprzed-

11 FeR 5.

12 Por. M. Chmielewski, dz. cyt., s. 685.

13 J.J. Garrido, Misja Chrześcijanina w czasach kryzysu kultury, „Communio” 1994, nr 6, s. 76.

14 Benedykt XVI, Szukajmy nowych dróg ewangelizacji, „L'Osservatore Romano” (wyd. pol.) 2011, nr 12, s. 32.

15 Por. M. Chmielewski, dz. cyt., s. 685-686.

16 D. Folscheid, Moralność naturalna czy wynaturzenie moralności? w: Moralność chrześcijańska. Kolekcja Communio, red. P. Góralczyk, Pallotinum, Poznań - Warszawa 1987, s. 165. 
miotowieniu. Zakwestionowane zostały również kryteria estetyki. Sztuka w ujęciu postmodernistów ma poszerzać horyzonty samospełniania się. Znaki i symbole religijne zdają się nie mieć znaczenia uniwersalnego i są interpretowane dowolnie. Założenia postmodernistycznej sztuki prowadzą do relatywizacji kultury, która coraz częściej staje się transgresyjną, tzn. łamiącą wszelkie zasady etyczne i estetyczne ${ }^{17}$.

Depersonalizujący indywidualizm stał się fundamentem autoekspresji jednostki. Postmodernizm głosi, że narzucanie lub egzekwowanie jakichkolwiek norm prawnych, etycznych czy estetycznych jest nie tylko bezprawne, bo łamie wolność, ale także ogranicza rozwój jednostki, odbierając jej niepowtarzalną indywidualność. Dlatego im bardziej ekscentryczne postawy reprezentuje dana osoba, tym bardziej zasługuje na uznanie jej twórczy przejaw indywidualności ${ }^{18}$. W społeczeństwie lansuje się tzw. antypedagogikę, głoszącą wyczerpanie się tzw. kultury postfiguratywnej, w której dzieci i młodzież kształtowani są na wzór i podobieństwo rodziców. Obecnie rozwija się kultura kofiguratywna, w której rodzice nadal odgrywają podstawową rolę, ale pozostają w stosunkach partnerskich wobec swoich dzieci (pobłażliwa obojętność). Po niej nastąpi przejście do kultury prefiguratywnej, w której to rodzice będą zmuszeni podporządkować się dzieciom. Spowodowane postępem technologicznym współczesne przyspieszenie rozwoju dzieci i młodzieży domaga się, aby to dorośli uczyli się od nich właściwych postaw i zachowań. Antypedagogika głosi, że dziecko odpowiada za swoje życie na równi z dorosłymi i posiada zdolność decydowania o sobie od chwili urodzenia. Przykładem mogą być kraje skandynawskie, gdzie istnieje możliwość zaskarżenia rodziców przez dziecko, gdy usiłują egzekwować swoje wymagania wychowawcze. Skutkiem takiego zachowania jest rozluźnienie więzi osobowych i pozbawienie ich wymiaru emocjonalnego. Następuje przyzwolenie dla tzw. wolnej miłości i wolnych związków. Widoczny jest niemal powszechny konsensus mediów co do pornografii ${ }^{19}$.

Antyracjonalizm i dekonstrukcjonizm kwestionują ważną ideę celu, zwłaszcza ostatecznego. W postmodernizmie człowiek nie powinien trzymać się raz wytyczonego celu, by ten nie ograniczał go. Ma prawo, a nawet powinność dokonywać ustawicznej zmiany: poglądów, zachowań, pracy, miejsca zamieszkania, a nawet partnera w związku uczuciowym. Powinien kierować się tym, co niesie chwila obecna. Zakorzenienie się w przeszłości, w historii i tradycji jest reliktem cywilizacji zbudowanej na racjonalizmie ${ }^{20}$. Pluralizm w sferze prawdy i moralności doprowadza do atomizacji społeczeństwa. Skoro nie ma jednej prawdy i wspólnych wartości, wobec tego język ojczysty, tradycja i wspólna historia, rodzina itd. tracą

17 Por. M. Chmielewski, dz. cyt., s. 686.

18 Por. tamże.

19 Por. tamże, s. 686-687.

20 Por. tamże, s. 687. 
swoją wartość. Dziś miarą lojalności obywatelskiej nie jest umiłowanie ojczyzny (patriotyzm), lecz płacenie podatku, bez którego nie może funkcjonować ekonomia i nie mogą być zaspokajane potrzeby konsumpcyjne. Nie liczy się zatem człowiek, lecz jego pieniądz ${ }^{21}$. Eksponowana przez postmodernizm indywidualność tylko pozornie kłóci się ze zjawiskiem standaryzacji. Ponieważ człowiek pozbawiony zakorzenienia w obiektywnym świecie wartości łatwo podlega manipulacji. Narzucone standardy są obliczone na konkretny ekonomiczny zysk. Prawom komercji podlega również informacja, od której szybkości uzależnione są operacje finansowe o dużej wartości. Im bardziej sensacyjna jest wiadomość, tym większą ma wartość. Stąd rodzi się nieujarzmiona pogoń za sensacją. Zadaniem mediów w tym ujęciu nie jest informowanie o rzeczywistości, lecz przede wszystkim jej kreowanie. Bardzo niebezpieczne jest oddziaływanie mediów przez tworzenie tzw. rzeczywistości wirtualnej. Największą w tym rolę odgrywa technika komputerowa (zwłaszcza gry komputerowe) oraz Internet. Fikcyjny obraz traktuje się jako realną rzeczywistość. Odbiorca takiego przekazu żyje jakby w stanie psychiczno-uczuciowego zamroczenia. Powoduje to ogromne spustoszenia w psychice i osobowości zwłaszcza dzieci i młodzieży, głównych konsumentów tychże mediów ${ }^{22}$.

\section{2. „BYĆ” CZY „MIEĆ”-MATERIALISTYCZNE POJMOWANIE ŚWIATA $W \dot{Z} Y C I U$ SPOEECZNYM}

Sytuacja współczesnego człowieka zdaje się być - mówiąc językiem św. Pawła służbą „ciała” a nie „ducha”: „Ciało bowiem pożąda przeciwko duchowi, a duch przeciwko ciału" (Ga 5,17). Dzieje się tak za sprawą materializmu. Odnosząc się do tego zjawiska Jan Paweł II w rozmowie z André Frossardem użył określenia „materializm praktyczny”, podkreślając niebezpieczeństwo polegające na podstępnym jego działaniu - gdy zmysłowe doświadczanie przedmiotów nie narusza bezpośrednio utrwalonej hierarchii wartości ${ }^{23}$. Współczesny człowiek coraz bardziej ulega wpływowi „mentalności posesyjnej”24, hołdując zasadzie „mieć”, a zapominając o „być”, co spotyka się ze słuszną naganą moralną ${ }^{25}$. Postawa ${ }^{26}$ taka

21 Por. tamże.

22 Por. tamże.

23 A. Frossard, Nie lękajcie się! Rozmowy z Janem Pawłem II, tłum. A. Turowiczowa, Editrice Vaticana, Rzym 1982, s. 116-117.

24 Łac. possesio - posiadanie.

25 Człowiek staje się niewolnikiem posiadania i używania, nie bacząc na własną godność, na bliźniego, na dobro społeczeństwa, na samego Boga. Chrystus mówi: „Cóż bowiem za korzyść odniesie człowiek, choćby cały świat zyskał, a na swojej duszy szkodę poniósł?” (Mt 16,26).

26 Postawa rozumiana jako nastawienie, psychiczny i nerwowy stan gotowości, zorganizowany przez doświadczenie, wywierający ukierunkowany lub dynamiczny wpływ na relacje jednostki w stosunku do wszelkich przedmiotów czy sytuacji, z którymi ten stan jest związany. Względnie 
była już analizowana w nauczaniu społecznym Kościoła. Jan Paweł II mówi o niej: „Jest przecież dobrze znany fakt cywilizacji konsumpcyjnej, która ma swoje źródło w nadmiarze dóbr potrzebnych dla człowieka, dla całych społeczeństw - a chodzi tu właśnie o społeczeństwo bogate i wysoko rozwinięte - podczas gdy z drugiej strony inne społeczeństwa, przynajmniej szerokie ich kręgi, głodują, a wielu codziennie umiera $\mathrm{z}$ głodu, $\mathrm{z}$ niedożywienia. W parze $\mathrm{z}$ tym idzie jakieś nadużycie wolności jednych, co łączy się z niekontrolowaną etycznie postawą konsumpcyjną, przy równoczesnym ograniczaniu wolności drugich, tych, którzy odczuwają dotkliwie braki, którzy zostają zepchnięci w warunki nędzy i upośledzenia" ${ }^{27}$. Można stwierdzić, że egotystyczna deformacja wolności w postawie „mieć” skutkuje pozbawieniem wolności innych ludzi, zarówno w wymiarze indywidualnym, jak i globalnym. Jan Paweł II pojęciem „,konsumpcjonizm” określa „,...) styl życia, który wyżej stawia dążenie do tego, by mieć, aniżeli być, i chce więcej mieć nie po to, aby bardziej być, lecz by doznać w życiu jak najwięcej przyjemności"28. Papież stwierdza dalej: „,...) człowiek wnika w sieć fałszywych i powierzchownych satysfakcji, podczas gdy powinien spotkać się z pomocą autentycznej i konkretnej realizacji swojej osobowości" ${ }^{29}$. Według papieża posiadanie dóbr samo przez się nie doskonali człowieka, jeśli nie przyczynia się do dojrzewania i ubogacania jego „być”, czyli realizacji powołania ludzkiego poprzez przyjęcie autentycznej hierarchii wartości. „Zło nie polega na 'mieć' jako takim, ale na takim 'posiadaniu', które nie uwzględnia jakości i uporządkowanej hierarchii posiadanych dóbr. Jakości i hierarchii, które płyną z podporządkowania dóbr i dysponowania nimi «byciu» człowieka i jego prawdziwemu powołaniu" 30 - naucza Jan Paweł II. Najtrafniejszym komentarzem do tych słów byłoby przywołanie przypowieści o bogaczu, który umyślił sobie wykorzystać obfite zbiory dla używania życia. Jego upadek opatrzył św. Łukasz przestrogą: „Tak dzieje się z każdym, kto skarby gromadzi dla siebie, a nie jest bogaty przed Bogiem" (Łk, 12, 21). W encyklice Sollicitudo rei socialis papież mówi o dwóch problemach, z jakimi boryka się dzisiejszy świat: problemie niedorozwoju, jak i „nadrozwoju”. Obok wciąż istniejącego problemu głodu na świecie, dostrzega zjawisko nadmiernego rozwoju objawiającego się poprzez nadmiar rozporządzania wszelkiego typu dobrami materialnymi na korzyść niektórych warstw społecznych. Zjawisko to łatwo prze-

trwała i zgodna organizacja wiedzy, uczuć oraz wzorców zachowania jednostki, związana z określonym przedmiotem lub klasą przedmiotów. Ze względu na przedmiot można wyróżnić postawy: moralne, społeczne, polityczne, religijno-duchowe, rzeczowe, interpersonalne, intrapersonalne. Por. za: I. Niewiadomska, Postawa, w: Leksykon duchowości katolickiej, red. M. Chmielewski, Wydawnictwo M, Lublin - Kraków 2002, s. 684.

27 RH 16.

28 CA 36.

29 Tamże, 41.

30 SRS 28. 
mienia ludzi w niewolników „posiadania” i natychmiastowego zadowolenia. Ciągła pogoń za coraz większą ilością dóbr lub zastępowanie ich coraz doskonalszymi, łączy się z wyrzucaniem „bezwartościowych” przedmiotów, które mogłyby stać się wartościowe dla kogoś uboższego. Ślepe poddanie się czystej konsumpcji prowadzi do rażącego materializmu i radykalnego nienasycenia. Uleganie wszechobecnej reklamie i kuszącym propozycjom nabycia produktów powoduje to, że im więcej się posiada, tym więcej się pożąda. W takim przypadku najgłębsze potrzeby człowieka pozostają niezaspokojone, a nawet zagłuszone ${ }^{31}$.

Regułom zysku (komercjalizacji) podlega niemal każda dziedzina życia: nauka, oświata, kultura, sport a nawet religia. Kierują nimi nie znawcy danego przedmiotu - naukowcy, pedagodzy, twórcy, sportowcy czy duchowni - ale specjaliści od marketingu. Organizacyjnym zapleczem tych obszarów życia jest rozbudowany przemysł reklamowo-sondażowy, sztucznie stymulujący społeczeństwo konsumpcyjne. Towarzyszy temu bezwzględna standaryzacja towarów, usług, zachowań społecznych i wzorców estetycznych. Przejawem tego typu procesów w Polsce są m.in. wszechobecna sieć gastronomiczna McDonald's, telewizyjne programy rozrywkowe o identycznej formie organizacyjnej a nawet graficznej, nadawane w różnych wersjach językowych, style mody i zachowań nierzadko obcych lokalnej kulturze, a nawet nazewnictwo (,pub” zamiast „bar”, „lunch” zamiast „obiad” itp. $)^{32}$. Można odnieść dziś wrażenie, że we współczesnym społeczeństwie wszystko musi się opłacać. Nawet polityka społeczna, czyli coś, co powinno powodować rozwój społeczny, poddaje się kalkulacji obliczonej na zysk ${ }^{33}$. „Człowiek epoki dostatku nie egzystuje już, jak uprzednio i odwiecznie, w środowisku innych ludzi, lecz otoczony jest przez przedmioty" ${ }^{\prime 34}$ - zauważa francuski filozof Jean Baudrillard. Handel w niedzielę nie ma być tylko udogodnieniem dla zapominalskich, którzy nie zdążyli kupić chleba, ale stał się strategią wykorzystania czasu wolnego, która ma służyć napędzaniu koniunktury gospodarczej poprzez zwiększoną konsumpcję. Dawniej ,„pasożytem społecznym” był ten, kto nie chciał pracować, a dzisiaj ten, kto nie chce konsumować ${ }^{35}$.

Czas wolny rodzi nowe potrzeby. Idealny członek społeczeństwa konsumpcyjnego na spacer niedzielny idzie nie do parku, ale do nowoczesnego centrum handlowego. Jest ono skonstruowane na kształt nowoczesnych centrów miast, w których człowiek ma przechadzać się jak po parku, albo po starym mieście alejami pomiędzy fontannami, kawiarniami, restauracjami, sklepami, kinami

31 Tamże, 28; RH 28.

32 Por. M. Chmielewski, dz. cyt., s. 54-55.

33 Por. T. Biedrzycki, dz. cyt., s. 321.

34 J. Baudrillard, Społeczeństwo konsumpcyjne-jego mity i struktury, tłum. S. Królak, Wydawnictwo Sic!, Warszawa 2006, s. 7.

35 Por. Z. Bauman, Praca, konsumpcjonizm, nowi ubodzy, tłum. S. Obirek, Wydawnictwo WAM, Kraków 2006, s. 54-55. 
i rozmaitego rodzaju punktami usługowymi. Dla kompletności nowoczesnego centrum miasta coraz częściej postuluje się, aby stanął tam również kościół. Nowoczesny człowiek nie powinien już bezowocnie marnować czasu na spacer po lesie. Ma przechadzać się pomiędzy regałami sklepów i ladami punktów usługowych, aby - konsumując - napędzać koniunkturę gospodarczą ${ }^{36}$. Ks. Tomasz Biedrzycki zauważył, że tak rozumiane społeczeństwo postindustrialne ${ }^{37}$ redukuje człowieka jedynie do „mieć”, a zysk staje się „,bożkiem”, któremu nie wolno nie służyć. Staje się on jedynym kryterium ludzkiego postępowania, co przyczynia się do degradacji etycznej człowieka. W tym miejscu duchowny przypomina za Pawłem VI, że prawdziwy rozwój musi mieć zawsze charakter integralny, czyli ma dotyczyć człowieka we wszystkich jego wymiarach i obejmować wszystkich ludzi. Nie wykluczać nikogo i nie ograniczać się tylko do wymiaru materialnego ${ }^{38}$. Codzienne funkcjonowanie nie spełnia się już w kontaktach z bliźnimi, ale poprzez ciągły odbiór i manipulowanie informacjami. Począwszy od urządzeń technicznych gospodarstwa domowego, aż do wszechobecnych komputerów i komunikatorów, zastępujących bezpośrednią relację ,ja-ty”, po rozrywkę i sport. Nowoczesne środki komunikacji paradoksalnie oddaliły, a nie zbliżyły ludzi do siebie. Wiemy, co się dzieje na drugiej półkuli, ale nie wiemy, co się dzieje u sąsiada za ścianą. Człowiek pozostaje całkowicie w relacji ,ja-telewizor”. Drugi człowiek, żyjący nieopodal, jest anonimowym sąsiadem (chyba że zakłóca naszą prywatność). Telefon przyczynił się do zaniku spontanicznych kontaktów międzyludzkich, ponieważ nie wypada dziś przyjść do kogoś niezapowiedzianym. Zapowiedź z kolei zobowiązuje do wcześniejszego przygotowania się, co sprawia, że wielu ogranicza się do minimum - rozmowa telefoniczna, albo wręcz kontakt wirtualny ${ }^{39}$. Żyjemy w epoce „singli”. Człowiek jest całkowicie skoncentrowany na sobie i zaspokajaniu własnych potrzeb. Dzięki urządzeniom technicznym jest samowystarczalny i samotny w relacji ,,ja-przedmioty”. „Ty” jest już niepotrzebne ${ }^{40}$. Konsumpcja ma zawsze wymiar indywidualny ${ }^{41}$. Nie istnieje konsumpcja kolektywna, stąd społeczeństwo konsumpcyjne preferuje indywidualizm. Nawet praca staje się bardziej samotnicza, dzięki rozmaitym formom telepracy - tak, by człowiek nie musiał ruszać się ze swojej „samotni”. Sporty tradycyjne, uchodzące za gry zespołowe, za sprawą gier komputerowych można rozgrywać w pojedynkę. Owa samotność coraz częściej wychodzi ze świata wirtualnego w realny. By nie ograniczać swojej wolności, preferuje się bycie „singlem”. Stąd dzisiejsza moda

\footnotetext{
36 Por. T. Biedrzycki, Konsumpcjonizm jako nowa kwestia społeczna, „Studia Gdańskie” 2007, t. XXI, s. 320.

37 Termin współbrzmiący z postnowoczesnością.

38 Por. PP 6-11.

39 Por. T. Biedrzycki, dz. cyt., s. 321-323.

40 Por. tamże, s. 322.

41 Por. Z. Bauman, Praca, konsumpcjonizm, dz. cyt., s. 65.
} 
na wolne związki, aby bez zobowiązań zawsze móc się rozstać, by nic nie stracić z możliwości konsumpcji rozmaitych atrakcji życiowych, oferowanych przez rynek. Ewentualną decyzję o założeniu rodziny odkłada się na coraz później dopiero wówczas, gdy się już „użyje życia”"42.

Do następstw konsumpcjonizmu można zaliczyć liczne zagrożenia o charakterze społecznym: niesprawiedliwy podział dóbr i ogromne dysproporcje w poziomie zamożności pomiędzy poszczególnymi grupami społecznymi i całymi narodami $^{43}$, zniszczenie środowiska naturalnego $0^{44}$, kryzys rodziny, pornografia i prostytucja ${ }^{45}$, wszelkiego rodzaju uzależnienia, jak narkomania, alkoholizm itp. Zdaniem Josepha Ratzingera, późniejszego papieża Benedykta XVI, zjawisko coraz częstszego sięgania po narkotyki jest narzędziem chwilowego uwolnienia się od świata, którego się nie akceptuje. Świat współczesny traktuje człowieka wyłącznie jako istotę materialną i koncentruje się na zaspokajaniu jego potrzeb materialnych: „'Wielka podróż', której potrzebują ludzie za pomocą narkotyków, jest perwersyjną formą mistyki, ludzkiej potrzeby nieskończoności (...), narkotyk jest pseudomistyką w świecie, który nie wierzy, ale mimo wszystko nie może zlikwidować dążenia duszy do raju. W ten sposób narkotyk jest znakiem ostrzegawczym (...). Odkrywa próżnię naszego społeczeństwa, której nie zaradzą jego instrumenty" ${ }^{46}$. Ta forma eskapizmu jest dziś szczególnie groźna. Dostępność narkotyków bowiem z jednej strony, a powszechność poczucia społecznego wykluczenia $\mathrm{z}$ drugiej - ciągle się nasilają. Na temat postaw konsumpcyjnych wypowiada się w wielu dokumentach obecny papież Franciszek i zdecydowanie potwierdza wcześniej stawianą przez poprzedników tezę, że współczesny świat ogarnął kryzys antropologiczny, stawiający w centrum już nie człowieka, ale konsumpcję oraz interesy ekonomiczne: „Dzisiaj wszystko poddane jest prawom rywalizacji i prawu silniejszego, gdzie możny pożera słabszego. W następstwie tej sytuacji wielkie masy ludności są wykluczone i marginalizowane: bez pracy, bez perspektyw, bez dróg wyjścia. Samego człowieka uważa się za dobro konsumpcyjne, które można użyć, a potem wyrzucić" ${ }^{47}$. W swoich wypowiedziach Ojciec Święty przestrzega przed niepohamowaną konsumpcją przyjmującą postawę: „im więcej mam, tym więcej chcę", która stanowi przeszkodę w osiągnięciu szczęścia, a może tylko doprowadzić ludzkość do samozniszczenia: „Im bardziej serce danej osoby jest puste, tym bardziej potrzebuje ona rzeczy, które mogłaby kupić, posiadać i konsumować (...). Obsesja na tle konsumpcyjnego stylu

\footnotetext{
42 Por. T. Biedrzycki, dz. cyt., s. 322-323.

43 Por. VS 80; SRS 19; CA 35.

44 Por. tamże, 38.

45 Por. VS 80; ChL 38.

46 J. Ratzinger, Czas przemian w Europie. Miejsce Kościoła i świata, thum. M. Mijalska, Wydawnictwo M, Kraków 2005, s. 16.

47 EG 53.
} 
życia, zwłaszcza gdy bardzo niewielu jest w stanie tak żyć, może sprowokować jedynie przemoc i wzajemne zniszczenie"48. Dzisiejszy świat - zdaniem papieża - potrzebuje autentycznej zmiany stylu życia. Podejścia z determinacją do obecnego problemu. Zamiany postawy konsumpcyjnej na postawę ewangeliczną, na wzór świętego Franciszka z Asyżu, żyjącego w pełnej harmonii z Bogiem, z innymi ludźmi oraz z naturąa ${ }^{49}$. Nie jest rzeczą naganną pragnąć lepszego poziomu życia, ani rzeczy, które sprawiają przyjemność. Problem polega na budowaniu właściwej hierarchii wartości, aby dostrzec, że są wartości wyższe. Oprócz świata materii istnieje świat ducha. Obok ziemskich uciech jest życie wieczne ${ }^{50}$.

\section{ZAKOŃCZENIE}

W świecie współczesnym, którego kondycję często określa się terminami „postmodernizm”, „ponowoczesność”, obserwować można z niepokojem nasilenie postaw konsumpcyjnych. Wpływają one negatywnie na osobowość człowieka, degradując zarówno jednostki, jak i całe społeczeństwa. W jednostronnym rozwoju cywilizacji materialnej, przyjmującej postawę „mieć”, człowiek iluzorycznie stał się „"panem wszechświata' nie zważając, że równocześnie sam siebie od tego świata uzależnił, że podporządkował się działaniu wyzwolonych w nim sił energii, że staje się przedmiotem wielorakich manipulacji, którym ze swej strony nie ma czego przeciwstawić właśnie dlatego, że całą swą świadomość i wolność oddał wyłącznie 'światu'. I 'świat' mu ją zabrał w całości" ‘51. Dla prawdziwych chrześcijan, mających nadzieję i radość w sercu, najwyższą wartość stanowią dobra nieprzemijające, łączące się z postawą „,być”. Jest ona orientacją „przyszłościową”. Osoby takie stawiają sobie cele zgeneralizowane, czasowo odległe, obejmujące dużą część życia (tak przeszłość, jak i przyszłość), związane z wartościami duchowymi. Takie przeżywanie pozwala twórczo wracać do przeszłości, angażować się w imię wartości w to, co dzieje się ,teraz" i pozwala z nadzieją patrzeć w przyszłość. W tym, co wewnętrzne, w wartościach, takie osoby odnajdują odniesienia do reinterpretacji znaczenia faktów, zwłaszcza porażek, na przykład nieuniknionego cierpienia. Jednocześnie osoby te w swoim odnajdywaniu i przeżywaniu nadziei są względnie niezależne od zdarzeń zewnętrznych. Wierni postawie wyjścia ku innym (,ty” i „Ty” Boga), żyją otwarci na doświadczenia świata, wie-

${ }^{8}$ LSi 204.

49 Por. tamże, 66.

50 Por. T. Biedrzycki, dz. cyt., s. 329.

51 A. Frossard, dz. cyt., s. 118. 
dząc, że dominuje w nim dobro. W postawie ofiarowania szukają spełnienia sie$\mathrm{bie}^{52}$.

\section{Bibliografia}

Baudrillard J., Społeczeństwo konsumpcyjne - jego mity i struktury, thum. S. Królak, Wydawnictwo Sic!, Warszawa 2006.

Bauman Z., Ponowoczesne wzory osobowe, „Studia Socjologiczne” 1993, nr 2, s. 9.

Bauman Z., Praca, konsumpcjonizm, nowi ubodzy, tłum. S. Obirek, Wydawnictwo WAM, Kraków 2006.

Benedykt XVI, Szukajmy nowych dróg ewangelizacji, „L'Osservatore Romano” 2011 (wyd. pol.), nr 12, s 32.

Biedrzycki T., Konsumpcjonizm jako nowa kwestia społeczna, „Studia Gdańskie" 2007, t. XXI.

Chmielewski M., Postmodernizm, w: Leksykon duchowości katolickiej, red. M. Chmielewski, Wydawnictwo M, Lublin - Kraków 2006, s. 688.

Chrostowski W., Moderniści, postmoderniści i inni, „Ethos” 1996, nr 1-2, s. 5.

Folscheid D., Moralność naturalna czy wynaturzenie moralności? w: Moralność chrześcijańska. Kolekcja Communio, red. P. Góralczyk, Poznań - Warszawa 1987, s. 165.

Franciszek, Adhortacja apostolska „Evangelii gaudium”, Editrice Vaticana, Watykan 2013.

Franciszek, Encyklika „Laudatio si '”, Editrice Vaticana, Watykan 2015.

Frossard A., Nie lękajcie się! Rozmowy z Janem Pawtem II, thum. A. Turowiczowa, Editrice Vaticana, Rzym 1982.

Garrido J., Misja chrześcijanina w czasach kryzysu kultury, „Communio” 1994, nr 6, s. 76.

Gellner E., Postmodernizm, rozum i religia, tłum. M. Kowalczuk, Państwowy Instytut Wydawniczy, Warszawa 1997.

Giddens A., Nowoczesność i tożsamość. „Ja” i społeczeństwo w epoce późnej nowoczesności, Wydawnictwo Naukowe PWN, Warszawa 2001.

Grulkowski B., Przeżywanie czasowości w postawach ,być” $i$,,mieć”, „Studia Gdańskie" 1999, nr 12, s. 250-252.

Jan Paweł II, Adhortacja apostolska „Christifideles laici”, Editrice Vaticana, Watykan 1988.

Jan Paweł II, Encyklika ,Centesimus annus”, Editrice Vaticana, Watykan 1991. Jan Paweł II, Encyklika ,Fides et ratio”, Editrice Vaticana, Watykan 1985.

${ }_{52}$ Por. Grulkowski B., Przeżywanie czasowości w postawach „,być” $i$,,mieć”, „Studia Gdańskie” 1999, nr 12, s. 250-252. 
Jan Paweł II, Encyklika „Redemptor hominis”, Editrice Vaticana, Watykan 1979.

Jan Paweł II, Encyklika „Redemptoris missio”, Editrice Vaticana, Watykan 1990.

Jan Paweł II, Encyklika ,,Sollicitudo rei socialis”, Editrice Vaticana, Watykan 1987.

Jan Paweł II, Encyklika ,, Veritatis splendor”, Editrice Vaticana, Watykan 1993.

Konstytucja duszpasterska o Kościele w świecie wspótczesnym ,, Gaudium et spes”, w: Sobór Watykański II, Konstytucje, dekrety, deklaracje, Pallotinum, Poznań 2002, s. 579.

Niewiadomska I., Postawa, w: Leksykon duchowości katolickiej, red. M. Chmielewski, Wydawnictwo M, Lublin - Kraków 2002, s. 684.

Paweł VI, Encyklika „Populorum progressio”, Editrice Vaticana, Watykan 1967.

Ratzinger J., Czas przemian w Europie. Miejsce Kościoła i świata, thum. M. Mijalska, Wydawnictwo M, Kraków 2005.

Szacki J., Historia myśli socjologicznej, Wydawnictwo Naukowe PWN, Warszawa 2004.

Ziółkowski J., Kryzys wartości, „Communio” 1983, nr 6, s. 33.

\section{Streszczenie}

Artykuł prezentuje postmodernistyczny konsumpcjonizm jako współczesne zagrożenie dla integralnego rozwoju w wymiarze jednostkowym i społecznym. Konsumowanie dóbr jest niezbędne dla funkcjonowania człowieka. Postmodernizm czyni z tegoż konsumowania wartość autoteliczną, dowolnie profilowaną egoistycznymi pragnieniami jednostki do poszerzania władzy posiadania. Kultura konsumpcjonistyczna jest skrajnie materialistyczna. Prowadzi również do rozchwiania, a niekiedy wręcz do zaniku obiektywnych hierarchii wartości czy systemów zasad moralnych. Postmodernistyczny konsumpcjonizm uzasadnia w skrajnych przypadkach niesprawiedliwość społeczną. W kontekście nauczania zawartego w encyklice Sollicitudo rei socialis stwierdzić trzeba, iż egoistycznie ukierunkowany konsumpcjonizm wyraża się w przewadze „mieć” nad „być”, co hamuje integralny rozwój społeczny. Skuteczne przezwyciężanie postmodernistycznego konsumpcjonizmu dokonuje się poprzez przywrócenie dobrom naturalnym narzędziowego charakteru w ramach obiektywnego porządku etyczno-moralnego ukształtowanego na tradycji chrześcijańskiej.

Słowa kluczowe: postmodernizm, współczesne społeczeństwo, materializm, konsumpcjonizm, indywidualizm 
The Postmodern Consumerism

as an Anthropological Peril of the $21^{\text {st }}$ Century

\begin{abstract}
Summary
The paper presents the Postmodern consumerism as a current threat faced by the integrated development of individuals and societies. Consuming goods is vital process for the human life. However, the Postmodernism makes it a value in itself which can be freely adjusted as one pleases in the process of widening one's own sphere of dominion. The consumerist culture is extremely materialistic. It leads to the distortion or even to the disappearance of the objective hierarchy of values and moral rules. In some particular cases the Postmodern consumerism goes as far as defending the social injustice. In the light of the teaching of Sollicitudo rei socialis we must admit that the egoistically motivated consumerism expresses itself in the supremacy of to have over to be, which in turn inhibits the integrated social growth. One way to overcome the Postmodern consumerism is to bring back the concept of the auxiliary value of the material goods and to set it in the context of the ethical and moral system based on the Christian tradition.
\end{abstract}

Keywords: Postmodernism, contemporary society, materialism, consumerism, individualism 